\title{
A simplified method for the assessment of carbon balance in agriculture: an application in organic and conventional micro-agroecosystems in a long-term experiment in Tuscany, Italy
}

\author{
Giulio Lazzerini, ${ }^{1}$ Paola Migliorini, ${ }^{2}$ Valentina Moschini, ${ }^{1}$ Cesare Pacini,, Paolo Merante, ${ }^{1}$ \\ Concetta Vazzana' \\ ${ }^{1}$ Dipartimento di Scienze delle Produzioni Agroalimentari e dell'Ambiente, Università di Firenze; \\ 2Università di Scienze Gastronomiche, Bra (CN), Italy
}

\begin{abstract}
Many research works propose sophisticated methods to analyse the carbon balance, while only a few tools are available for the calculation of both greenhouse gas emissions and carbon sequestration with simplified methods. This paper describes a carbon balance assessment conducted at farm level with a simplified methodology, which includes calculations of both $\mathrm{CO}_{2}$ emissions and carbon sequestration in crop rotations. This carbon balance was tested in the Montepaldi Long Term Experiment (MOLTE) trial in central Italy, where two agroecosystems managed with two different farming practices (organic $v s$ conventional) are compared. Both in terms of $\mathrm{CO}_{2} \mathrm{eq}$ emissions and carbon sequestration, this simplified method applied in our experiment provided comparable results to those yielded by complex methodologies reported in the literature. With regard to the crop rotation scheme applied in the reference period (2003-2007), $\mathrm{CO}_{2}$ emissions from various farm inputs were found to be significantly lower $\left(0.74 \mathrm{Mg} \mathrm{ha}^{-1}\right)$ in the organically managed system than in the conventionally managed
\end{abstract}

Correspondence: Giulio Lazzerini, Dipartimento di Scienze delle Produzioni Agroalimentari e dell'Ambiente, Università di Firenze, Piazzale delle Cascine 18, 50144 Firenze, Italy.

E-mail: giulio.lazzerini@unifi.it

Key words: soil organic carbon, soil carbon sequestration, greenhouse gas emissions, farming systems, organic agriculture.

Acknowledgements: the authors wish to thank Giovanna Casella and Roberto Vivoli for their support for field data collection. This study was carried out within the framework of the SATEGRAS research project, funded by the ARSIA Agency of Regione Toscana (Tuscany regional authority), Italy.

Conference presentation: SIA XLII Congress, Reggio Calabria, 2013.

Received for publication: 27 November 2013.

Revision received: 4 February 2014.

Accepted for publication: 8 February 2014.

(C) Copyright G. Lazzerini et al., 2014

Licensee PAGEPress, Italy

Italian Journal of Agronomy 2014; 9:566

doi:10.4081/ija.2014.566

This article is distributed under the terms of the Creative Commons Attribution Noncommercial License (by-nc 3.0) which permits any noncommercial use, distribution, and reproduction in any medium, provided the original author(s) and source are credited. system $\left(1.76 \mathrm{Mg} \mathrm{ha}^{-1}\right)$. The same trend was observed in terms of $\mathrm{CO}_{2} \mathrm{eq}$ per unit of product $\left(0.30 \mathrm{Mg} \mathrm{kg}^{-1}\right.$ in the organic system and 0.78 $\mathrm{Mg} \mathrm{kg}^{-1}$ in the conventional system). In the conventional system the sources that contributed most to total emissions were direct and indirect emissions associated with the use of fertilisers and diesel fuel.

Also the stock of sequestered carbon was significantly higher in the organic system (27.9 $\mathrm{Mg} \mathrm{ha}^{-1}$ of $\mathrm{C}$ ) than in the conventional system (24.5 $\mathrm{Mg} \mathrm{ha}^{-1}$ of $\left.\mathrm{C}\right)$. The carbon sequestration rate did not show any significant difference between the two systems.

It will be necessary to test further this methodology also in commercial farms and to validate the indicators to monitor carbon fluxes at farm level.

\section{Introduction}

While, on the one hand, the agricultural sector contributes to greenhouse gas emissions, on the other it can also play a fundamental role in climate change mitigation through soil carbon sequestration. In particular, this is true for cropping systems which are based on specific conservation practices, such as minimum tillage, rotations and use of organic fertilisers (Robertson et al., 2000; Six et al., 2002; VandenBygaart et al., 2003) or are managed with organic farming methods (Drinkwater et al., 1998; West and Post, 2002; FA0, 2009).

Carbon dioxide $\left(\mathrm{CO}_{2}\right)$, methane $\left(\mathrm{CH}_{4}\right)$, and nitrous oxide $\left(\mathrm{N}_{2} \mathrm{O}\right)$ are the largest contributors to greenhouse gas (GHG) emissions from the agricultural sector (Snyder et al., 2009). These gases are converted into a $\mathrm{CO}_{2}$ equivalent, which expresses the relative contribution of a gas to the greenhouse effect (global warming potential, GWP) compared to carbon dioxide $\left(\mathrm{CO}_{2}\right)$ (Flessa et al., 2002). In 2009, the GHG emissions from agriculture were $34.5 \mathrm{Mt} \mathrm{CO}_{2}$ eq. Since 1990, in Italy, GHG emissions dropped at a rate of approximately 15\% compared with the total value for the entire period, mainly due to a decline in the number of livestock, the loss of cultivated areas, and particularly the reduction in the use of nitrogen fertilisers (ISPRA, 2012). In 2009, the agricultural sector was responsible for 7\% of total GHG emissions (ISPRA, 2012), being therefore the second source after the energy sector (83\%). Out of the three main greenhouse gases, $\mathrm{N}_{2} \mathrm{O}$ is the largest contributor from agriculture (IPCC, 1996). Nitrous oxide emissions correspond to about $45 \%$ of the total global anthropogenic emissions from the agricultural sector (ISPRA, 2012). Most of $\mathrm{N}_{2} \mathrm{O}$ emissions are produced in soils during nitrification and denitrification processes (Hutchinson and Davidson, 1993). The increase of $\mathrm{N}_{2} \mathrm{O}$ in cultivated soils is mainly due to the use of $\mathrm{N}$ inputs in mineral fertilisers, animal wastes and biological $\mathrm{N}$ fixation (IPCC, 1996). In organic farming, a low nitrogen input in soils reduces potential nitrous oxide emissions (El-Hage-Scialabba and Müller-Lindenlauf, 2010). 
In the literature there are a number of studies that investigate greenhouse gas emissions from agriculture. Audsley (1997), Ceuterick (1998), Kramer et al. (1999), Williams et al. (2006) and Warner et al. (2010) evaluated the emissions from different crops. Other authors estimated emissions from different farming system, such as Flessa et al., 2002; de Boer, 2003; Cederberg and Mattsson, 2000; Haas et al., 2001 who compared organic and conventional farming systems.

In two long-term comparative experiments with arable rotations, Niggli et al. (2007) and Nemecek et al. (2005) found that the global warming potential of all crops was reduced by $18 \%$ in organic cropping systems as compared to the conventional system. Küstermann et al., (2008) and Robertson et al. (2000) reported an even higher reduction in greenhouse gas emissions, i.e. $53 \%$ and $64 \%$, respectively.

The agricultural sector contributes significantly to carbon sequestration (FA0, 2009; Six et al., 2002; Smith et al., 2008; VandenBygaart et al. 2003; West and Post, 2002) by long crop rotations including legumes and organic fertilization (Leifeld and Fuhrer, 2010) and to the reduction of carbon loss as a result of conservative tillage systems (Roberson, et al., 2000). Carbon sequestration in agriculture correlates with the farming system adopted. Several studies have demonstrated that organically managed plots have a higher soil carbon content than conventionally managed ones (Mariott and Wander, 2006; MüllerLindenlauf, 2009; Stalenga and Kawalec, 2008; Küstermann et al., 2008; Niggli et al., 2009; Mondelaers et al., 2009; El-Hage-Scialabba and Müller-Lindenlauf, 2010; Gattinger et al., 2012).

Most of the above-mentioned research works were conducted using: i) complex methodologies, such as the life cycle analysis (LCA) Assessment to examine the contribution from different emission factors (Audsley, 1997; Ceuterick, 1998; Kramer et al., 1999; Williams et al., 2006; De Backer et al., 2009; Warner et al., 2010; Venkat, 2012); and ii) complex mathematical models to assess the carbon balance (Grace $e t$ al., 2006; Küstermann et al., 2008; Stockmann et al., 2013). However, it is also possible to calculate GHG emissions using simplified methods (Flessa et al., 2002; Lal, 2004). Simple empirical methods were also used to calculate carbon soil sequestration in terms of concentration of organic carbon, carbon stock and rate of carbon sequestration (Aguilera et al., 2013). Furthermore, only a few studies are available on the effect of management practices on both carbon sequestration and $\mathrm{CO}_{2}$ emissions (Küstermann et al., 2008). This is probably due to the remarkable complexity of methods and databases used for each of these two indicators, which becomes even greater in combined analyses. In our study we evaluated the carbon balance of two agroecosystems (organic $v s$ conventional) through a simplified set of indicators, which includes both carbon emissions (expressed as $\mathrm{CO}_{2} \mathrm{eq}$ ) and carbon sequestration of crop rotations. These indicators were selected within the framework of the SATREGAS project on the sustainability of farming systems and the promotion of crops with low $\mathrm{CO}_{2}$ emission developed in Tuscany (Italy). In our study, the set of SATREGAS indicators was tested on the organic and conventional micro-agroecosystems of the Montepaldi Long Term Experiment (MOLTE) at the experimental farm of the University of Florence (Italy), using data from the 20032007 period.

\section{Materials and methods}

\section{Study site}

The Montepaldi Long Term Experiment (MOLTE) has been ongoing since 1991 (Migliorini et al., 2013; Migliorini and Vazzana, 2007; Vazzana et al., 1997) at the experimental farm of the University of Florence (Montepaldi, San Casciano, Val di Pesa, Long. 1109' 08” E,
Lat. $43^{\circ} 40^{\prime} 16^{\prime \prime} \mathrm{N}$ ) in a slightly sloping area of about 15 hectares at 90 $\mathrm{m}$ asl. In the MOLTE experiment, three micro-agroecosystems were set up to investigate differences between organic, integrated and conventional management systems. In our study, we only considered data from the following two micro agroecosystems (Figure 1): i) the Old Organic (Old0) system of 5.2 ha, consisting of 4 fields under organic management since 1992 (EC reg. 2092/91 and following regulations; European Commission, 1991); ii) the Conventional system of 2.6 ha, consisting of 2 conventional fields managed with the farming techniques generally adopted by the local conventional farms.

The two agro-ecosystems are surrounded by ecological infrastructures, such as natural and artificial hedges, in order to avoid as much as possible any interaction effects and cross-contaminations among fields. The climatic conditions of the experimental area are typical of the Mediterranean sub-Apennine zone. The annual rainfall is about $770 \mathrm{~mm}$ with a peak in autumn and spring and a minimum in JuneAugust. The annual mean temperature is $14.1^{\circ} \mathrm{C}$ with a maximum which can exceed $30^{\circ} \mathrm{C}$ in summer and minimum temperatures in January.

The MOLTE soil is composed of parent rock material derived from Pliocene sediments (slopes) and river Pesa fluvial deposits from the Holocene (plane), classified as Fluventic Xerochrepts (Lulli et al., 1980). Based on the texture, this soil can be classified in between silty clay loam and clay loam with widespread gravel. Table 1 shows the main characteristics of the micro-agroecosystems analysed.

\section{Data collection}

In order to assess the soil organic carbon (SOC) concentration (mg $\mathrm{kg}^{-1}$ ), soil samples were collected and submitted to specific chemical analyses (i.e. Springer-Klee method; Springer and Klee, 1954).

Each soil sampling was performed with a hand probe reaching a depth of $30 \mathrm{~cm}$ in 4 areas. For each area a soil sample was obtained by mixing three sub-samples collected in the same area after removing the crop residues from the soil surface. In total, we collected 24 soil samples each year. At harvest, crop yields were measured on the entire area of the fields, using four samples of harvested fraction and crop residues for each field. Each crop sample was obtained by collecting three sub-samples which were subsequently mixed.

In order to obtain the yield's dry matter, the yield values were adjusted

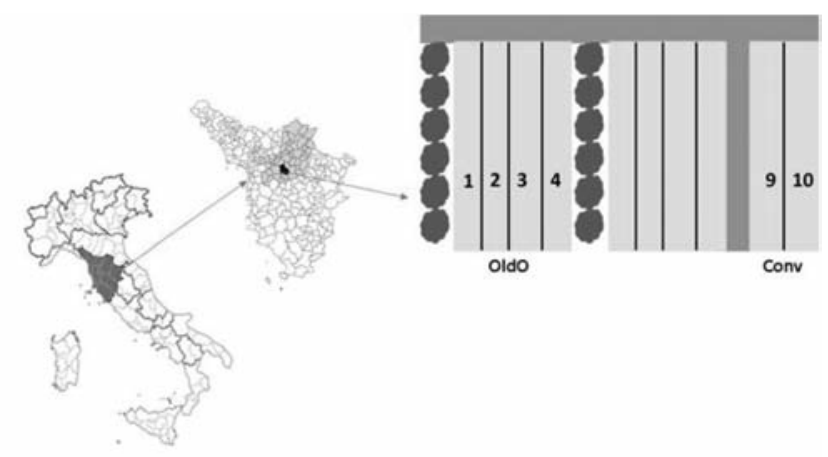

Figure 1. Location of the Montepaldi Long Term Experiment (MOLTE) on an organic (OldO) micro-ecosystem and a conventional (Conv) micro-agroecosystem close to Florence (Tuscany, Italy). 
Table 1. Characteristics of the two agroecosystems analysed at Montepaldi Long Term Experiment (Florence, Tuscany).

\begin{tabular}{|c|c|c|}
\hline Input & OldO & Conv \\
\hline Soil texture & Silty clay loam and clay loam & Silty clay loam and clay loam \\
\hline Crop rotation & $\begin{array}{l}\text { I: Green manure + Corn } \\
\text { II: Common/Durum Wheat or Barley + overseeding Clover } \\
\text { III: Clover } \\
\text { IV: Common/Durum Wheat }\end{array}$ & $\begin{array}{l}\text { I: Corn } \\
\text { II: Common/Durum Wheat or Barley }\end{array}$ \\
\hline Tillage & $\begin{array}{l}\text { 2003-2007: plow/ripper }(25 \mathrm{~cm}) / \\
\text { disc arrow }(2 \text { times } 20 \mathrm{~cm})\end{array}$ & $\begin{array}{l}\text { 2003-2007: plow/ripper }(25 \mathrm{~cm}) / \\
\text { disc arrow }(2 \text { times } 20 \mathrm{~cm})\end{array}$ \\
\hline $\begin{array}{l}\text { Input } \\
\text { Fertiliser: nitrogen }\left(\mathrm{kg} \mathrm{ha}^{-1}\right) \\
\text { Fertiliser: phosphorus }\left(\mathrm{kg} \mathrm{ha}^{-1}\right) \\
\text { Fertiliser: potassium }\left(\mathrm{kg} \mathrm{ha}^{-1}\right) \\
\text { Crop residues nitrogen }\left(\mathrm{kg} \mathrm{ha}^{-1}\right) \\
\text { Herbicides }\left(\mathrm{l} \mathrm{ha}^{-1}\right) \\
\text { Fuel }\left(\mathrm{l} \mathrm{ha}^{-1}\right)\end{array}$ & $\begin{array}{l}\text { OldO } \\
9.9 \\
8.5 \\
1.7 \\
34.6 \\
0.0 \\
146.5\end{array}$ & $\begin{array}{l}\text { Conv } \\
81.0 \\
56.9 \\
0.0 \\
25.2 \\
4.1 \\
144.1\end{array}$ \\
\hline Harvest $\left(\mathrm{Mg} \mathrm{ha}^{-1}\right)^{\circ}$ & $\begin{array}{l}\text { Barley: } 4.0 \\
\text { Common wheat: } 2.5 \\
\text { Durum Wheat: } 3.2 \\
\text { Corn: } 2.3 \\
\text { Clover: } 3.9\end{array}$ & $\begin{array}{l}\text { Barley: } 4.7 \\
\text { Common wheat: } 6.2 \\
\text { Durum wheat: } 3.5 \\
\text { Corn: } 1.7\end{array}$ \\
\hline
\end{tabular}

OldO, Old Organic; Conv, Conventional. ${ }^{\circ}$ Annual average of the crop rotation.

on the basis of the humidity content. The biomasses of the crop residues (i.e. straw and root residues) were calculated using the harvest index $[\mathrm{HI}=0.40$ for maize; 0.45 for winter cereals (wheat and barley) $]$ and shoot root ratio [We assumed the following shoot:root ratio: 5.60 for maize, 9.46 for wheat, 6.81 for barley, and 0.70 for annual clover.].

\section{Statistical analysis}

The experimental data collected from each system in the 2003-2007 period were processed by a univariate analysis of variance (ANOVA) with fixed model using SPSS 16.0 statistical software package.

\section{Processing methods of global warming potential indicators}

The GWP is defined as the cumulative radiative forcing between the present and a selected time in the future, caused by a unit mass of gas emitted now (IPCC, 1996). The three gasses, $\mathrm{CO}_{2}, \mathrm{CH}_{4}$ and $\mathrm{N}_{2} \mathrm{O}$ are converted into a $\mathrm{CO}_{2}$ equivalent value $\left(\mathrm{CO}_{2} \mathrm{eq}\right)$ using the coefficients of 1 , 25 and 298, respectively over a time span of 100 years (IPCC, 2006).

The GWP was calculated in terms of carbon emissions per unit of area $\left(\mathrm{Mg} \mathrm{ha}^{-1}\right.$ of $\left.\mathrm{CO}_{2} \mathrm{eq}\right)$ and per unit of product $\left(\mathrm{Mg} \mathrm{kg}^{-1}\right.$ of $\left.\mathrm{CO}_{2} \mathrm{eq}\right)$, using the following inputs: fuel $\left(\mathrm{L} \mathrm{ha}^{-1}\right)$, herbicides $\left(\mathrm{kg} \mathrm{ha}^{-1}\right)$, fertilisers [nitrogen $(\mathrm{N})$, phosphorus $(\mathrm{P})$, potassium $(\mathrm{K}) ; \mathrm{kg} \mathrm{ha}^{-1}$ ] and farm machinery $\left(\mathrm{hr} \mathrm{ha}{ }^{-1}\right)$ (Table 1$)$.

For the calculation of the GWP index $\left(\mathrm{CO}_{2} \mathrm{eq}\right)$, the emission factors, defined as average emission rate of a given GHG for a given source relative to units of activity (IPCC, 1996), were derived from data on greenhouse gas emissions reported in the literature (Table 2).

Emissions due to loss of $\mathrm{N}_{2} \mathrm{O}$ from fertilised soil and soil crop residues

The Intergovernmental Panel on Climate Change (IPCC, 2006) established a direct $\mathrm{N}_{2} \mathrm{O}$ emission coefficient of $1 \%$ for nitrogen inputs of chemical fertilisers, organic fertilisers and the amount of $\mathrm{N}$ in crop residues. In terms of $\mathrm{CO}_{2} \mathrm{eq}$, this emission factor corresponds to $2.98 \mathrm{~kg}$ $\mathrm{kg}^{-1}$ (Table 2). While the nitrogen content of synthetic fertilisers can be inferred from the literature, for crop residues it was calculated using laboratory tests (Pregi/Dumas methods; Simon, 1962). The IPCC (2006) considered an indirect $\mathrm{N}_{2} \mathrm{O}$ emission factor for evaporated
Table 2. Emission factors used for the calculation of $\mathrm{CO}_{2}$ eq.

\begin{tabular}{lcc} 
Emission factors & $\begin{array}{c}\mathrm{CO}_{2} \mathrm{eq} \\
\left(\mathrm{kg} \mathrm{kg}^{-1}\right)\end{array}$ & Reference \\
$\mathrm{N}_{2} \mathrm{O}$ direct application of nitrogen fertiliser & 2.98 & IPCC, 2006 \\
$\mathrm{N}_{2} \mathrm{O}$ direct application of crop residues & 2.98 & IPCC, 2006 \\
\hline $\mathrm{N}_{2} \mathrm{O}$ indirect volatilization fertiliser & 0.5 & IPCC, 2006 \\
$\mathrm{N}_{2} \mathrm{O}$ indirect leached fertiliser & 3.5 & IPCC, 2006 \\
\hline $\mathrm{N}$ fertiliser production & 2.86 & Küstermann et al., 2008 \\
$\mathrm{P}$ fertiliser production & 2.57 & Küstermann et al., 2008 \\
\hline $\mathrm{K}$ fertiliser production & 0.73 & Küstermann et al. 2008 \\
Herbicide production & 26.63 & Audsley et al., 2009 \\
\hline Diesel & 3.17 & IPCC, 1996 \\
Manufacture machine & 1.17 & Doering, 1980 \\
\hline
\end{tabular}

$\mathrm{N}$, nitrogen; P, phosphorus; K, potassium.

ammonia and nitrogen (including the fraction emitted as $\mathrm{N}_{2} \mathrm{O}$ ) of 0.5 $\mathrm{kg} \mathrm{CO}_{2} \mathrm{eq} \mathrm{kg}^{-1}$ and $3.5 \mathrm{~kg} \mathrm{CO}_{2} \mathrm{eq} \mathrm{kg}^{-1}$, respectively (Table 2).

\section{Emissions from production of chemical fertilisers and herbicides}

In this research the following emission factors were used for fertilisers: $\mathrm{N}$ fertilisers $2.86 \mathrm{~kg} \mathrm{CO}_{2} \mathrm{eq} \mathrm{kg}{ }^{1}$, P fertilisers $2.57 \mathrm{~kg} \mathrm{CO}_{2} \mathrm{eq} \mathrm{kg}^{-1} ; \mathrm{K}$ fertilisers $0.73 \mathrm{~kg} \mathrm{CO}_{2} \mathrm{eq} \mathrm{kg}^{-1}$ (Küstermann et al., 2008) (Table 2). The calculation of $\mathrm{CO}_{2} \mathrm{eq}$ emissions from the production of fertilisers is then performed by multiplying the amount of fertiliser $(\mathrm{kg})$ by the corresponding emission factors. Emissions of herbicides were calculated following Audsley et al. (2009), based on the quantity of product used (in terms of herbicide active ingredient) and an emission factor of

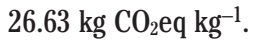

Emissions from consumption of fuels and use of machinery

The $\mathrm{CO}_{2}$ eq emission was calculated (Flessa et al., 2002) by multiplying the amount of fuel used (kg) by an emission factor of $3.17 \mathrm{~kg} \mathrm{~kg}^{-1}$ of $\mathrm{CO}_{2} \mathrm{eq}$ (Table 2). Audsley (1997) argued that the only practical way 
to estimate $\mathrm{CO}_{2} \mathrm{eq}$ emissions resulting from the use of agricultural machinery is to consider the energy required for producing them (expressed in $\mathrm{MJ} \mathrm{kg}^{-1}$ of the machine's mass/weight) and converting it into $\mathrm{kg} \mathrm{CO}_{2} \mathrm{eq}$. For these calculations, we first divided the machine's mass by the total hours of life of the machine itself (hourly charge of the machine's mass). Then, this value was multiplied by the hours needed to perform an operation for each crop and was subsequently converted in $\mathrm{MJ} \mathrm{kg}^{-1}$ (Audsley, 1997). For the conversion we used Doering's coefficients (1980) of $14.6 \mathrm{MJ} \mathrm{kg}^{-1}$ for tractors and $8.6 \mathrm{MJ}$ $\mathrm{kg}^{-1}$ for other farm machinery. Lastly, these values were converted into $\mathrm{CO}_{2} \mathrm{eq}$ by multiplying them by a conversion factor of $0.074 \mathrm{~kg} \mathrm{MJ}^{-1}$ (IPCC, 2006).

\section{Carbon sequestration processing method}

The calculation of carbon sequestration was performed using 2 indicators: the stock of SOC $\left(\mathrm{Mg} \mathrm{C} \mathrm{ha}^{1}\right)$ and the carbon sequestration rate

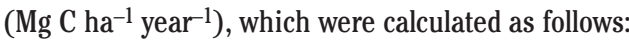

$$
\mathrm{SOC}_{\text {stock }}=\mathrm{BD} \times \mathrm{SOC}_{\text {conc }} \times \mathrm{D}
$$

where $\mathrm{BD}$ is soil bulk density $\left(\mathrm{Mg} \mathrm{m}^{-3}\right), \mathrm{SOC}_{\text {conc }}$ is the concentration of soil organic carbon ( $\mathrm{mg} \mathrm{kg}^{-1}$ ), and D is the thickness of the soil layer (m). BD was estimated according to Post and Kwon (Post and Kwon, 2000):

$$
\mathrm{BD}=100 /\left[0 \mathrm{~m}_{\text {cond }} / 0.244+\left(100-0 \mathrm{~m}_{\text {conc }}\right) / 1.64\right]
$$

where 0.244 is the bulk density of soil organic matter, 1.64 is the bulk density of soil mineral matter, and $\mathrm{Om}_{\text {conc }}$ is the concentration of soil organic matter (\%), which was estimated according to Springer- Klee method (Springer and Klee, 1954).

The $\mathrm{C}$ sequestration rate $\left(\mathrm{Mg} \mathrm{C} \mathrm{ha}^{-1}\right.$ year-1) $\left.^{-1}\right)$ was calculated with the following equation:

$$
\mathrm{C} \text { sequestration rate }=\left(\mathrm{Ct}_{\mathrm{t}}-\mathrm{Ct}_{\mathrm{o}}\right) / \mathrm{t}
$$

where $\mathrm{Ct}_{\mathrm{t}}$ and $\mathrm{Ct}_{0}$ represent $\mathrm{SOC}$ stocks $\left(\mathrm{Mg} \mathrm{C} \mathrm{ha}^{-1}\right)$ at the end and at the beginning of the experiment, respectively, and $t$ refers to the duration of the experiment (years).

\section{Results}

\section{Greenhouse gas emissions}

With regard to the crop rotation applied during the reference period (2003-2007), the values of $\mathrm{CO}_{2}$ eq emissions for the Old0 system (0.74 $\mathrm{Mg} \mathrm{ha}^{-1}$ ) were significantly lower than those of the Conv system (1.76
$\mathrm{Mg} \mathrm{ha}^{-1}$ ). In fact the emission level of $\mathrm{CO}_{2} \mathrm{eq}$ from the organic system was $60 \%$ lower than that of the conventional system (Table 3 ).

The sources having the highest impact on total emissions in the Conv system were diesel fuel and the application and production of nitrogen fertilisers (Figure 2 and 3B). More than 55\% of GHG emissions were attributed to the application and production of nitrogen fertilisers, while $25 \%$ was due to fuel combustion/use (Figure 3B).

In the Old0 system the largest contribution to emissions (over 60\% of the total emissions of $\mathrm{CO}_{2} \mathrm{eq}$ ) came from the use of fuel, while $30 \%$ of emissions were attributed to the production and application of nitrogen fertilisers (Figure 3A). Crop residues generated a higher loss of $\mathrm{N}_{2} \mathrm{O}$ (i.e. $14 \%$ of the total emissions; Figure $3 \mathrm{~A}$ ) in the OldO system than in the Conv system. Nevertheless, these residues had a positive impact on the increase of the carbon sink in the soils under organic management. Also the $\mathrm{CO}_{2} \mathrm{eq}$ emissions per unit of product were significantly different between the 0ld 0 farming system $\left(0.30 \mathrm{Mg} \mathrm{kg}^{-1}\right)$ and the conventional system $\left(0.78 \mathrm{Mg} \mathrm{kg}^{-1}\right)$ (Table 3$)$.

\section{Carbon sequestration}

The carbon stock in the two farming systems was found to be statistically different: the carbon stock was $14 \%$ higher $\left(27.9 \mathrm{Mg} \mathrm{ha}^{-1}\right)$ in the Old0 system compared to the Conv system (24.5 $\mathrm{Mg} \mathrm{ha}^{-1}$ ) (Table 3).

The rate of carbon sequestration instead was not significantly different between the two farming systems $\left(0.48 \mathrm{Mg} \mathrm{ha}^{-1}\right.$ year $^{-1}$ in the 0ld0 system and $-0.54 \mathrm{Mg} \mathrm{ha}^{-1}$ year-1 in the Conv system) (Table 3 ).

\section{Discussion}

\section{Set of indicators for the calculation of the carbon balance}

While various sophisticated methods for the carbon balance analysis at farm level have been developed (Venkat, 2012; Küstermann et al., 2008), only a few tools are available for the calculation of both GHG emissions $\left(\mathrm{CO}_{2} \mathrm{eq}\right)$ and carbon sequestration with simplified methods.

GHG emissions can be calculated using simple or more complex methods, such as for example the LCA analysis. There is currently a growing body of literature on LCA-based methods for assessing the environmental impact of single crops or production processes (Williams et al., 2006; Meisterling et al., 2009; Venkat, 2012).

These studies reported a reduction of $\mathrm{CO}_{2} \mathrm{eq}$ emissions in organic systems as compared to conventional systems. This is in line with what we found in our investigation using simplified methods for indicator calculation. Only Nemecek et al. (2011) found a reduction of $\mathrm{CO}_{2} \mathrm{eq}$ emissions in conventional systems.

In keeping with the results of Pelletier et al. (2008) and De Backer et al. (2009), we have shown that the reduction of $\mathrm{CO}_{2} \mathrm{eq}$ emissions from organic farming depends on the application and production of fertilisers, even if we have observed a slightly higher use of fuel in

Table 3. Analysis of variance: average and significance of greenhouse gas emissions per unit of area $\left(\mathrm{Mg} \mathrm{ha}^{-1}\right)$ and per unit of product

\begin{tabular}{|c|c|c|c|c|c|}
\hline Source of variation & Degrees of freedom & $\begin{array}{l}\mathrm{CO}_{2} \text { eq emission } \\
\left(\mathrm{Mg} \mathrm{ha}^{-1}\right)\end{array}$ & $\begin{array}{l}\mathrm{CO}_{2} \text { eq emission } \\
\left(\mathrm{Mg} \mathrm{ha}^{-1}\right)\end{array}$ & $\begin{array}{l}\text { Soil carbon stock } \\
\qquad(\mathrm{Mg} \mathrm{ha}-1)\end{array}$ & $\begin{array}{c}\text { Carbon sequestration rate } \\
\left(\mathrm{Mg} \mathrm{ha}^{-1}\right)\end{array}$ \\
\hline System (S) & 1 & $* *$ & $* *$ & $* *$ & n.s. \\
\hline OldO & - & $0.74+0.11$ & $0.30+0.07$ & $27.93+0.53$ & $0.48+0.70$ \\
\hline Conv & - & $1.76+0.11$ & $0.78+0.07$ & $24.51+0.75$ & $-0.54+0.99$ \\
\hline
\end{tabular}
$\left(\mathrm{Mg} \mathrm{kg}^{-1}\right)$, soil carbon stock $\left(\mathrm{Mg} \mathrm{ha}^{-1}\right)$ and carbon sequestration rate $\left(\mathrm{Mg} \mathrm{ha}^{-1} \mathrm{year}^{-1}\right)$ for each farming system depending on the source of variation in the 2003-2007 period.

** Significant with $\mathrm{P} \leq 0.01$; *significant with $\mathrm{P} \leq 0.05$. n.s. not significant; OldO, Old Organic; Conv, Conventional. 
the organic micro-agroecosystem.

The changes in soil organic carbon can be estimated using a simple methodology or more complex soil carbon models. Küstermann et al. (2008) analysed carbon cycles in farming systems using a simulation model of carbon fluxes in the soil. In our study the calculated mean of C sequestration was $0.37 \mathrm{Mg} \mathrm{ha}^{-1} \mathrm{yr}^{-1}$ for the organic system and -0.25 $\mathrm{Mg} \mathrm{ha}^{-1} \mathrm{yr}^{-1}$ for the conventional system. Rühling et al. (2005) reported similar results (a SOC increase by $0.18 \mathrm{Mg} \mathrm{ha}^{-1} \mathrm{yr}^{-1}$ in the organic system and a SOC decrease by $0.12 \mathrm{Mg} \mathrm{ha}^{-1} \mathrm{yr}^{-1}$ in the conventional system).

In line with those studies, also in our experiment we found a comparable SOC increase in the organic system as compared to the conventional system ( $0.48 \mathrm{Mg} \mathrm{ha}^{-1} \mathrm{yr}^{-1}$ and $-0.54 \mathrm{Mg} \mathrm{ha}^{-1} \mathrm{yr}^{-1}$, respectively).

\section{Impacts of organic and conventional practices on carbon balance}

On the basis of the results and the statistical analysis performed, we can note the effects of farm management on carbon balance. In our study we have shown that organic farming positively affects GHG emissions and SOC stock compared to the conventional farming system as reported in the literature by other authors (Mäder et al., 2002; Nemecek, et al., 2005; Niggli et al., 2009; Leifeld and Fuhrer, 2010; ElHage-Scialabba and Müller-Lindenlauf, 2010; Gattinger et al., 2012).

\section{$\mathrm{CO}_{2}$ eq emissions}

In organic farming the $\mathrm{CO}_{2}$ eq emissions per unit of area and per unit of product are respectively $58 \%$ and $61 \%$ lower than in conventional agriculture. Various studies reported comparable results (Robertson $e t$ al., 2000; Nemecek, et al., 2005; Küstermann et al., 2008). According to Küstermann et al. (2008), GHG emissions due to fuel consumption and use of machinery are nearly similar in both organic and conventional cropping rotations. On the contrary, in our experiment we have identified a large difference, which is mainly due to the contribution of $\mathrm{N}_{2} \mathrm{O}$ to total GHG emissions (45\% for the conventional system and $26 \%$ for the organic system) that can be ascribed to the synthetic-chemical $\mathrm{C}$ used in the conventional farming system.

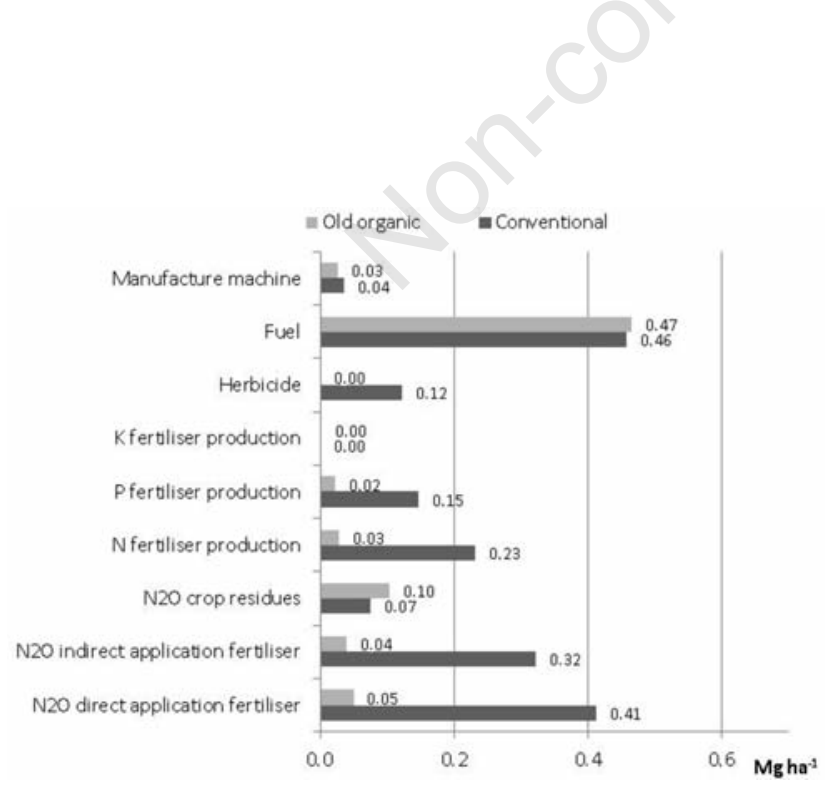

Figure 2. Average greenhouse gas emission $\left(\mathrm{Mg} \mathrm{CO}_{2} \mathrm{eq} \mathrm{ha}^{-1}\right)$ of the organic micro-agroecosystem and the conventional microagroecosystem in relation to different types of activities in the 2003-2007 period.
The contribution in terms of $\mathrm{GHG}$ emission of $\mathrm{N}_{2} \mathrm{O}$ was found to be the most important source of agricultural emissions (Flessa et al., 2002; Mäder et al., 2002, Olesen et al. 2006) and accounts for $38 \%$ of agricultural GHG emissions overall (El-Hage-Scialabba and Muller, 2010). In the organic farming system, both the ban on the use of mineral nitrogen and the addition of green manure in the crop rotations to improve the soil structure (Mathieu, et al., 2006) reduced $\mathrm{N}_{2} \mathrm{O}$ emissions by decreasing the concentration of readily available mineral nitrogen in the soil.

\section{C sequestration}

Gattinger et al. (2012) proved that both the SOC concentration and the SOC stock in soils under organic management are significantly higher than in non-organic farming management. In keeping with the
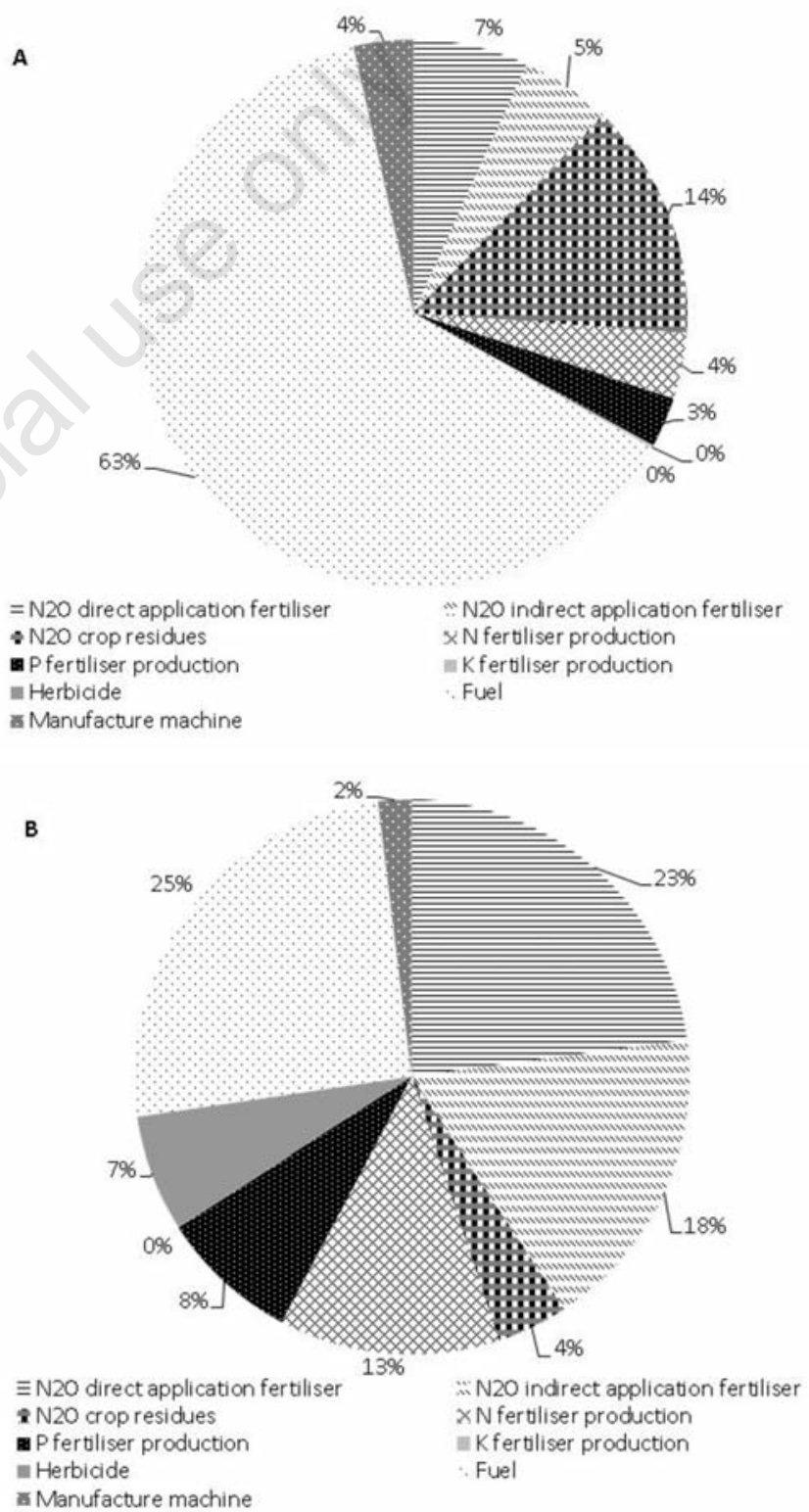

Figure 3. Greenhouse gas emissions $\left(\mathrm{CO}_{2} \mathrm{eq}\right)$ for the organic micro-agroecosystem and the conventional micro-agroecosystem (percentage). A) Old organic; B) Conventional. 
results of Gattinger et al., also in our study we found that the soils under organic management stocked $3.4 \mathrm{Mg} \mathrm{C}$ ha ${ }^{1}$ more than soils under conventional management. This value is derived by calculating the difference between soil carbon stocks in the organic system and in the conventional system, as described in Table 3). Instead, unlike Gattinger et al. (2012), we did not observe a significant difference in terms of carbon sequestration rate between the two farming systems. This result can be probably ascribed to the short period of our analysis. Ellert et al. (2001) argued that a period of 5 years is not sufficient to obtain statistically significant results in terms of carbon sequestration rate. Marriott and Wander (2006) reported that the increase of SOC sequestration by about $14 \%$ in organic systems vs conventional systems occurred on average after 10 years.

The same tillage used in the two management systems affected the carbon sequestration rate. Probably in the organic system the benefits in terms of carbon sequestration resulting from the application of carbon input (from cover crops, crop rotation and green manure) are partly lost due to the use of conventional tillage (for example ploughing) that accelerates the mineralisation process.

Even though it is widely acknowledged that different types of tillage affect the SOC concentration in soils under organic management, the results yielded by different research works are not univocal, because the effects can differ depending on the different pedoclimatic conditions (Alluvione et al., 2013). Teasdale et al., (2007) found a significantly higher carbon concentration in the organic system compared to the no-till system. Wells et al. (2000) and Küstermann et al. (2008) found a significantly higher organic carbon content in the organic system which did not involve the use of minimum tillage. Leifeld and Fuhrer (2010) and Robertson et al. (2000) emphasized the need to apply the carbon input to the soil with minimum or no-tillage.

\section{Conclusions}

In our study we have applied a simplified methodology to assess the carbon balance in a long-term experiment conducted in the MOLTE trial of the University of Florence.

Both in terms of $\mathrm{CO}_{2} \mathrm{eq}$ emissions and carbon sequestration, the simplified methods applied provided comparable results to those found with complex methodologies reported in the literature.

Regarding $\mathrm{CO}_{2} \mathrm{eq}$ emissions, the simplified methodology applied showed a reduction of GHG emissions in the organic system compared to the conventional system. Furthermore, the results indicate a minor involvement of the organic system in the emission of greenhouse gases per unit of area and per unit of product compared to the conventional one ( $58 \%$ and $61 \%$ less $\mathrm{CO}_{2} \mathrm{eq}$ respectively).

Also in terms of carbon sequestration, the chemical tests for SOC calculation showed an increase of SOC in the organic system that is comparable to the results obtained with complex models for the calculation of soil carbon fluxes reported in the literature.

Organically managed soils have stocked $3.4 \mathrm{Mg} \mathrm{C} \mathrm{ha}^{-1}$ (in five years) more the soils under conventional management. The carbon sequestration rate of the period under study did not show a significant difference between the two management systems. The same tillage used in the two farming systems, probably, affected this parameter.

These results are confirmed in numerous studies published recently (Küstermann et al., 2008; Leifeld and Fuhrer, 2010; El-Hage-Scialabba and Müller-Lindenlauf, 2010; Gattinger et al., 2012), which highlight that organic systems can have more positive effects on the carbon balance by reducing the use of inputs and increasing soil carbon sequestration.
In the future it will be important to validate the simplified set of indicators adopted in the MOLTE under different pedoclimatic conditions by comparing it with observed data and results of more complex simulation models, with the objective of extending its use to commercial farms.

\section{References}

Aguilera E, Lassaletta L, Gattinger A, Gimeno BS, 2013. Managing soil carbon for climate change mitigation and adaptation in Mediterranean cropping systems: a meta-analysis. Agric. Ecosyst. Environ. 168:25-36.

Alluvione F, Fiorentino N, Bertora C, Zavattaro L, Fagnano M, Quaglietta Chiarandà F, Grignani C, 2013. Short-term crop and soil response to C-friendly strategies in two contrasting environments. Eur. J. Agron. 45:114-23.

Audsley E (Coordinator), 1997. Harmonisation of environmental life cycle assessment for agriculture. Final Report, Concerted Action AIR3-CT94-2028. European Commission, DG VI Agriculture, pp 139.

Audsley E, Stacey AK, Parsons DJ, Williams AG, 2009. Estimation of the greenhouse gas emissions from agricultural pesticide manufacture and use. Cranfield University, pp 20. Available from: http://dspace.lib.cranfield.ac.uk/handle/1826/391

Cederberg C, Mattsson B, 2000. Life cycle assessment of milk production - a comparison of conventional and organic farming. J. Cleaner Prod. 8:49-60.

Ceuterick D (Ed.), 1998. Proc. International Conference on Application of Life Cycle Assessment in Agriculture, Food and Non-Food AgroIndustry and Forestry, 3-4 December, Brussels, Belgium.

De Backer E, Aertsens J, Vergucht S, Steurbaut W, 2009. Assessing the ecological soundness of organic and conventional agriculture by means of life cycle assessment (LCA): A case study of leek production. Br. Food J. 111:1028-61.

de Boer I, 2003. Environmental impact assessment of conventional and organic milk production. Livestock Prod. Sci. 80:69-77.

Doering OC, 1980. Accounting for energy in farm machinery and buildings. In: D. Pimentel (ed.), Handbook of energy utilization in agriculture. CRC Press, Boca Raton, FL, pp 9-14.

Drinkwater LE, Wagoner P, Sarrantonio M, 1998. Legume-based cropping systems have reduced carbon and nitrogen losses. Nature $396: 262-5$.

El-Hage-Scialabba N, Müller-Lindenlauf M, 2010. Organic agriculture and climate change. Renew. Agr. Food Syst. 25:158-69.

Ellert BH, Janzen H, McConkey BG, 2001. Assessment methods for soil carbon storage In: R. Lai, J.M. Kimble, R.F. Follett and B.A. Stewart (Eds.), Assessment methods for soil carbon. Lewis Publishers, Boca Raton, FL, pp 131-46.

European Commission, 1991. Council Regulation (EEC) No 2092/91 of 24 June 1991 on organic production of agricultural products and indications referring thereto on agricultural products and foodstuffs. In: Official Journal, L 198, 22/7/1991, available from: http://eur-lex.europa.eu/LexUriServ/LexUriServ.do?uri=CONSLEG: 1991R2092:20060506:EN:PDF

FAO, 2009. Organic agriculture and carbon sequestration. Possibilities and constrains for the consideration of organic agriculture within carbon accounting systems. Natural Resources Management and Environment Department, Food and Agriculture Organization of the United Nations, Rome.

Flessa H, Ruser R, Dörsch P, Kampb T, Jimenez MA, Munch JC, Beese $\mathrm{F}, 2002$. Integrated evaluation of greenhouse gas emissions (CO2, CH4, N20) from two farming systems in southern Germany. Agric. Ecosyst. Environ. 91:175-89. 
Gattinger A, Muller A, Haeni M, Skinner C, Fliessbach A, Buchmann N, Mäder P, Stolze M., Smith P, El-Hage-Scialabba N, Niggli U, 2012. Enhanced top soil carbon stocks under organic farming. Proc. Natl. Acad. Sci. U. S. A. 109:18226-31.

Grace PR, Ladd JN, Robertson GP, Gage SH, 2006. SOCRATES - a simple model for predicting long-term changes in soil organic carbon in terrestrial ecosystems. Soil Biol. Biochem. 38:1172-6.

Haas G, Wetterich F, Kopke U, 2001. Comparing intensive, extesified and organic grassland farming in southern Germany by process life cycle assessment. Agric. Ecosyst. Environ. 83: 43-53.

Hutchinson GL, Davidson EA, 1993. Processes for production and consumption of gaseous nitrogen oxides in soil. In: L.A. Harper, A.R. Mosier and J.M. Duxbury (eds.), Agricultural ecosystems on trace gases and global climate change. ASA Publ. 55. ASA-CSSA-SSSA, Madison, WI, pp 79-93.

IPCC - Intergovernmental Panel on Climate Change, 1996. Revised IPCC guidelines for national greenhouse gas inventories: reference manual. IPCC, London.

IPCC - Intergovernmental Panel on Climate Change, 2006. IPCC guidelines for national greenhouse gas inventories, prepared by the Greenhouse Gas Inventories Programme, H.S. Eggleston, L. Buendia, K. Miwa, T. Ngara and K. Tanabe (eds.). IGES, Hayama, Japan.

ISPRA - Istituto Superiore per la Protezione e la Ricerca Ambientale, 2012. Annuario dei dati ambientali 2011. ISPRA, Rome. [In Italian]. Available from: http://annuario.isprambiente.it/sites/ default/files/pdf/2011/tematiche/PARTE\%20GENERALE_0.pdf

Kramer KJ, Moll HC, Nonhebel S, 1999. Total greenhouse gas emissions related to the dutch crop production system. Agric. Ecosyst. Environ. 72:9-16.

Küstermann B, Kainz M, Hülsbergenet KJ, 2008. Modelling carbon cycles and estimation of greenhouse gas emissions from organic and conventional farming systems. Renew. Agric. Food Syst. 23:38-52.

Lal R, 2004. Carbon emission from farm operations. Environ. Int. 30:981-90.

Leifeld J, Fuhrer J, 2010. Organic farming and soil carbon sequestration: What do we really know about the benefits? Ambio 39:585-99.

Lulli L, Lorenzoni P, Arretini A, 1980. Esempi di cartografia tematica e di cartografia derivata (Sezione Lucignano, Foglio Firenze). La carta dei suoli, la loro capacità d'uso, l'attitudine dei suoli all'olivo e al Sangiovese. C.N.R., Progetto Finalizzato Conservazione del Suolo, Istituto Sperimentale lo Studio e la Difesa del Suolo, Firenze. pp 95. [In Italian].

Mader P, Fliebach A, Dubois D, Gunst L, Fried P, Niggli U, 2002. Soil fertility and biodiversity in organic farming. Science 296:1694-7.

Marriott E, Wander M, 2006. Total and labile soil organic matter in organic and conventional farming systems. Soil Sci. Soc. Am. J. 70:950-9.

Mathieu 0, Lévêque J, Hénault C, Milloux M-J, Bizouard F, Andreux F, 2006. Emissions and spatial variability of N20, N2 and nitrous oxide mole fraction at the field scale, revealed with $15 \mathrm{~N}$ isotopic techniques. Soil Biol. Biochem. 38:941-51.

Meisterling K, Samaras C, Schweizer V, 2009. Decisions to reduce greenhouse gases from agriculture and product transport: LCA case study of organic and conventional wheat. J. Cleaner Prod. 17:222-30.

Migliorini P, Moschini V, Tittarelli F, Ciaccia C, Benedettelli S, Vazzana C, Canali S, 2013. Agronomic performance, carbon storage and nitrogen utilisation of long-term organic and conventional stockless arable systems in Mediterranean area. Eur. J. Agron. 52:138-45.

Migliorini P, Vazzana C, 2007. Biodiversity indicators for sustainability evaluation of conventional and organic agro-ecosystems. Ital. J. Agron. 2:105-10.
Mondelaers K, Aertsens J, Van Huylenbroeck G, 2009. A meta-analysis of the differences in environmental impacts between organic and conventional farming. Br. Food J. 111:1098-19.

Müller-Lindenlauf M, 2009. Organic agriculture and carbon sequestration. Possibilities and constrains for the consideration of organic agriculture within carbon accounting systems. Natural Resources Management and Environment Department, Food and Agriculture Organization of the United Nations, Rome.

Nemecek T, Dubois D, Huguenin-Elie 0, Gaillard G, 2011. Life cycle assessment of Swiss farming systems: I. Integrated and organic farming. Agric. Syst. 104:217-32.

Nemecek T, Huguenin-Elie 0, Dubois D, Gaillard G, 2005. Ökobilanzierung von Anbausystemen im Schweizerischen Acker- und Futterbau Schriftenreihe der FAL 58. FAL Reckenholz, Zürich.

Niggli U, Schmid H, Fliessbach A, 2007. Organic farming and climate change. Doc. No. MDS-08-152.E. International Trade Centre UNCTAD/WTO and Research Institute of Organic Agriculture (FiBL), Geneva, pp 27.

Niggli U, Fließbach A, Hepperly P, El-Hage-Scialabba N, 2009. Low greenhouse gas agriculture: mitigation and adaptation potential of sustainable farming systems. Food and Agriculture Organization of the United Nations, Rome.

Olesen JE, Schelde K, Weiske A, Weisbjerg MR, Asman WAH, Djurhuus J, 2006. Modelling greenhouse gas emissions from European conventional and organic dairy farms. Agric. Ecosyst. Environ. 112:207-20.

Pelletier N, Arsenault N, Tyedmers P, 2008. Scenario modeling potential eco-efficiency gains from a transition to organic agriculture: life cycle perspectives on Canadian canola, corn, soy, and wheat production. Environ. Manage. 42:989-1001.

Post WM, Kwon KC, 2000. Soil carbon sequestration and land-use change: processes and potential. Global Change Biol. 6:317-27.

Robertson GP, Paul EA, Harwood RR, 2000. Greenhouse gases in intensive agriculture: contributions of individual gases to the radiative forcing of the atmosphere. Science 289:1922-5.

Rühling I, Ruser R, Kölbl A, Priesack E, Gutser R, 2005. Kohlenstoff und Stickstoff in Agrarökosystemen. In: E. Osinski, A. Meyer-Aurich, B. Huber, I. Rühling, G. Gerl, and P. Schröder (eds.), Landwirtschaft und Umwelt: ein Spannungsfeld. oekom Verlag, München, pp 99-154.

Simon W, 1962. Chimia 16:312.

Six J, Callewaert P, Lenders S, De Gryze S, Morris SJ, Gregorich EG, Paul EA, Paustian K, 2002. Measuring and understanding carbon storage in afforested soils by physical fractionation. Soil Sci. Soc. Am. J. 66:1981-7.

Smith P, Martino D, Cai Z, Gwary D, Janzen H, Kumar P, McCarl B, Ogle S, O'Mara F, Rice C, Scholes B, Sirotenko 0, Howden M, McAllister T, Pan G, Romanenkov V, Schneider U, Towprayoon S, Wattenbach M, Smith J, 2008. Greenhouse gas mitigation in agriculture. Philos. Trans. R Soc. Lond. B Biol. Sci. 363:789-813.

Snyder CS, Bruulsema TW, Jensen TL, Fixen PE, 2009. Review of greenhouse gas emissions from crop production systems and fertiliser management effects. Agric. Ecosyst. Environ. 133:247-66.

Springer U, Klee J, 1954. Prufung der Leistungsfa higkeit von einigen wichtigen Verfahren zur Bestimmung des Kohlenstoffs mittels Chromschwefelsaure sowie Vorschlag einer neuen Schnellmethode. J. Plant Nutr. Soil Sci. 64:1-26.

Stalenga J, Kawalec A, 2008. Emissions of greenhouse gases and soil organic matter balance in different farming systems. Int. Agrophys. 22:287-90

Stockmann U, Adams MA, Crawford JW, Field DJ, Henakaarchchi N, Jenkins M, Minasny B, McBratney AB, de Remy de Courcelles V, Singha K, Wheeler I, Abbott L, Angers DA, Baldock J, Bird M, Brookes PC, Chenu C, Jastrow JD, Lal R, Lehmann J, O'Donnell AG, Parton WL, Whitehead D, Zimmermann M, 2013. The knowns, 
known unknowns and unknowns of sequestration of soil organic carbon. Agric. Ecosyst. Environ. 164:80-99.

Teasdale JR, Coffmann CB, Magnum RW, 2007. Potential long-term benefits of no-tillage and organic cropping systems for grain production and soil improvement. Agron. J. 99:1297-305.

VandenBygaart AJ, Gregorich EG, Angers DA, 2003. Influence of agricultural management on soil organic carbon: a compendium and assessment of Canadian studies. Canadian J. Soil Sci. 83:363-80.

Vazzana C, Raso E, Pieri S, 1997. Una nuova metodologia europea per la progettazione e gestione di agroecosistemi integrati ed ecologici: applicazione in un'area agricola Toscana. Riv. Agron. 31: 423-40. [In Italian].

Venkat K, 2012. Comparison of twelve organic and conventional farming systems: a life cycle greenhouse gas emissions perspective. J.
Sustain. Agric. 36:620-49.

Warner DJ, Davies M, Hipps N, Osborne N, Tzilivakis J, Lewis KA, 2010. Greenhouse gas emissions and energy use in UK-grown short-day strawberry (Fragaria xananassa Duch) crops. J. Agric. Sci. 148:667-81.

Wells T, Chan KY, Cornish PE, 2000. Comparison of conventional and alternative vegetable farming systems on the properties of a yellow earth in New South Wales. Agric. Ecosyst. Environ. 80:47-60.

West T0, Post WM, 2002. Soil organic carbon sequestration rates by tillage and crop rotation: a global data analysis. Soil Sci. Soc. Am. J. 66:1930-46.

Williams AG, Audsley E, Sandars DL, 2006. Determining the environmental burdens and resource use in the production of agricultural and horticultural commodities. Final Report on DEFRA Research Project IS0205. DEFRA, London. 